\title{
Preliminary Considerations About the Transposition of Directive 2013/34/EU Into Italian Accounting System
}

\author{
Roberta Provasi \\ Università degli Studi di Milano, Milan, Italy \\ Claudio Sottoriva \\ Università Cattolica del Sacro Cuore, Milan, Italy
}

\begin{abstract}
With the Directive No. 2013/34/EU dated June 26, 2013, the Parliament and the European Council have decreed a new era for the financial statements of companies in the EU member countries. The introduction of the new directive aims to improve the coverage information of the accounting document and to begin a process of simplification of administrative burdens and standards for the preparation and publication of the financial statements. In Italy, the directive must be transposed by July 20, 2015 for which the associations of accountants are evaluating the specific contents of the new rules to make applications for Italian companies. Some of the new rules and above all part of the new structures of the schemes of the financial statements are quite different from the approaches currently in use for which very heated discussions are taking place.
\end{abstract}

Keywords: European Directive 2013/34/EU, Italian accounting system, accounting harmonization

\section{Introduction}

The purpose of the new European Directive 2013/34/EU of June 26, 2013 is to renew the legislation on the financial statements and the consolidated financial statements too by repealing the previous two European directives, namely, the No. 660 dated 1978 known as IV Directive and the No. 349 of 1983, known as the EEC Directive VII. The objectives of this update are:

(1) To encourage the process of European accounting harmonization so that the financial statements of the companies are drawn up following the same rules of form and content and therefore perfectly comparable;

(2) To find an appropriate balance between the stakeholders and the need for firms to not be overly burdened by obligations of accounting information (Combarros, 2000).

In fact, the new directive takes account of the provisions contained in the European Commission (2010) adopted in October 2010, titled "Smart Regulation in the European Union", which aims to develop high standards of quality while ensuring a balance between the information requested and the burden of obligations imposed on businesses. The economic reality of the EU is in fact made up of mostly small- and medium-sized enterprises (SMEs) to which the directive is addressed through simplifications and exemptions.

Roberta Provasi, assistant professor, Dipartimento di Scienze Economico-Aziendali e Diritto per l’Economia, Università degli Studi di Milano. Email: roberta.provasi@unimib.it.

Claudio Sottoriva, assistant professor, Dipartimento di Scienze dell’Economia e della Gestione Aziendale, Università Cattolica del Sacro Cuore. 
The reason is to avoid excessive costs for small businesses to comply with the disclosure requirements imposed. The directive also refers to the European Commission communication, entitled "Think Small First: A New Basic Framework for the Small Business (A Small Business Act for Europe)”, adopted in June 2008 and revised in February 2011, which recognizes a central role to SMEs in the EU economy and aims to improve the overall approach to entrepreneurship. Another reference is to the commission communication, entitled "The High Single Market Act” enacted in April 2011, which aims to simplify the IV and VII Directives in order to improve the business climate and promote the internationalization especially for small- and medium-sized businesses (Sottoriva, 2014).

Finally, on December 18, 2008, the European Parliament adopted a resolution stating that the accounting directives are often very burdensome for SMEs asking precisely the commission for a review of those directives. The objective of this research is to analyze the main changes introduced by the Directive 2013/34 and especially the effects on SMEs.

It should be stressed that the directive has not yet been introduced (will be implemented by July 20, 2015). So, this study highlights some considerations on the proposed new regulations resulting from the implementation of the updated directive, in particular, the reflections that the scientific-cultural debate is fueling as a result of the participation of the National Council of Certified Accountants to public consultation for the implementation of the directive. The Italian accountants have a thorough understanding of the issues and difficulties of SMEs so that their contribution to the transposition and implementation of the new regulations is fundamental and indispensable.

The transposition of the directive is the final step started in 2002 when the European Parliament and Council issued the Regulation (EC) No. 1606/2002, according to which listed companies on any financial market within the EU were required, starting in 2005, to refer to International Financial Reporting Standards (IFRS) as accounting standards of reference for the preparation of their annual consolidated financial statements. Moreover, the same regulation granted member states the power to permit or require other companies "to prepare their consolidated accounts and/or their annual accounts in compliance with the international accounting standards”. Through the enactment of Legislative Decree No. 38/2005, Italy made an extensive use of the power granted by the EU and required that companies with financial instruments that appear among the general public in large numbers, banks, insurance companies, and other financial entities subject to the supervision of the Bank of Italy prepare their consolidated accounts (as of 2005) and individual accounts (as of 2006) in compliance with IFRS. Moreover, as of 2006, all listed companies and listed insurance companies that do not prepare consolidated accounts have been required to adopt IFRS for their individual accounts. Finally, with only few exceptions, since 2005, all non-listed companies have been entitled to adopt IFRS to prepare their consolidated accounts. Companies included in the consolidation area of those companies that prepare their consolidated financial statements in compliance with IFRS are also entitled to prepare their individual accounts according to IFRS (Corbella, Florio, \& Rossignoli, 2013).

Therefore, until 2004, all Italian limited companies - but the same is for all other European countries were required to prepare their individual and consolidated financial statements according to the national regulation that followed the IV and VII European Directives, respectively on individual and consolidated accounts, while starting from 2005, we have assisted to a composite situation, with companies which comply with IFRS and companies which continue applying Italian regulation and the Generally Accepted Accounting Principles (GAAP). 
This research also contributes to disseminating internationally the arguments for and against future legislation in order to feed a comparison with the approaches pursued by other jurisdictions. The research does not take into consideration the new provisions contained in the directive relating to the consolidated financial statements, the corporate groups, the audit, and other specific aspects.

\section{The New Directive: Scope and General Provisions for the Preparation of the Financial Statements}

Pursuant to Art. 3 of the new directive, the beneficiaries of the legislation were grouped based on quantitative criteria to distinguish micro-enterprises from small, medium-sized, and large enterprises while in the case of business groups are separated by small groups, groups of medium-sized, and large groups. Table 1 shows the characteristics and the quantitative limits in order to identify the different categories of firms.

Table 1

Quantitative Criteria to Distinguish Enterprises

\begin{tabular}{|c|c|c|}
\hline Company & Criteria & Directive 2013/34/EU \\
\hline $\begin{array}{l}\text { Micro-enterprises: companies that at } \\
\text { the date of the financial statement } \\
\text { do not exceed the limits of at least } \\
\text { two of the following three criteria }\end{array}$ & $\begin{array}{l}\text { (1) Total balance sheet: } € 350,000 \\
\text { (2) Net revenues from sales and services: } \\
€ 700,000 \\
\text { (3) Average number of employees during the } \\
\text { financial year: } 10\end{array}$ & $\begin{array}{l}\text { Article } 36 \text { provides for the simplification in } \\
\text { the preparation of the balance sheet, income } \\
\text { statement, and notes to the financial } \\
\text { statements. Other simplifications are } \\
\text { provided for the preparation of the } \\
\text { management report and the publication of } \\
\text { the financial statements }\end{array}$ \\
\hline $\begin{array}{l}\text { Small companies: companies that at } \\
\text { the date of the financial statement } \\
\text { do not exceed the limits of at least } \\
\text { two of the following three criteria }\end{array}$ & $\begin{array}{l}\text { (1) Total balance sheet: } € 4,000,000 \\
\text { (2) Net revenues from sales and services: } \\
€ 8,000,000 \\
\text { (3) Average number of employees during the } \\
\text { year: } 50\end{array}$ & $\begin{array}{l}\text { According to Article } 14 \text {, member states may } \\
\text { authorize small companies to draw up a } \\
\text { balance sheet and income statement in } \\
\text { abbreviated form. Other simplifications are } \\
\text { provided for in Article } 31 \text { for the publication } \\
\text { of the financial statements }\end{array}$ \\
\hline $\begin{array}{l}\text { Medium-sized companies: companies } \\
\text { that at the date of financial statement } \\
\text { do not exceed the limits of at least } \\
\text { two of the following three criteria }\end{array}$ & $\begin{array}{l}\text { (1) Total balance sheet: } € 20,000,000 \\
\text { (2) Net revenues from sales and services: } \\
€ 40,000,000 \\
\text { (3) Average number of employees during the } \\
\text { financial year: } 250\end{array}$ & $\begin{array}{l}\text { According to Article } 14 \text {, member states may } \\
\text { authorize these companies to prepare an } \\
\text { income statement in abbreviated form. They } \\
\text { must provide additional information in the } \\
\text { notes in accordance with Article } 17\end{array}$ \\
\hline $\begin{array}{l}\text { Large companies: companies that at } \\
\text { the date of balance sheet exceed the } \\
\text { limits of at least two of the } \\
\text { following three criteria }\end{array}$ & $\begin{array}{l}\text { (1) Total balance sheet: } € 20,000,000 \\
\text { (2) Net revenues from sales and services: } \\
€ 40,000,000 \\
\text { (3) Average number of employees during the } \\
\text { financial year: } 250\end{array}$ & $\begin{array}{l}\text { These must provide appropriate additional } \\
\text { information in the notes in accordance with } \\
\text { the provisions of Articles } 17 \text { and } 18\end{array}$ \\
\hline Public interest entities (PIEs) & $\begin{array}{l}\text { These are always considered big businesses } \\
\text { regardless of the net revenues from sales and } \\
\text { services, the total assets on the balance sheet, } \\
\text { and the average number of employees during } \\
\text { the year }\end{array}$ & $\begin{array}{l}\text { They must provide additional information in } \\
\text { the notes in accordance with the provisions } \\
\text { of Articles } 17 \text { and } 18\end{array}$ \\
\hline
\end{tabular}

This new directive consolidates, modernises, and updates the previous directives governing this area of regulation. It introduces a building block approach to the statutory financial statements that companies prepare, with increasing the levels of disclosure depending on the size of the enterprise. It seeks to increase the comparability of financial reports across member states by reducing the number of options available to prepare financial statements in respect of recognition, measurement, and presentation. Further, for the first time, the accounting directive creates a largely harmonised small company regime and limits. The effects of this for Italian accounting system are relevant, because Italy had not already implemented many of the options previously available that form the basis for this new regime. 
The directive emphasises the type of accounting information to be published by companies and establishes minimum equivalent legal requirements as regards the extent of the financial information that should be made available to the public. The scope of this directive is principles-based and aims to ensure that each company cannot exclude itself from that scope by creating a group structure containing multiple layers of enterprises established inside or outside the Union. Under the directive, this information will be based on the size of the companies and company groups, determined by three variables: volume of assets, turnover, and the average number of employees. According to the directive, it is necessary to strike an appropriate balance between the interests of the addressees of the financial statements and the burden that the companies must endure to comply with the reporting requirements. The directive simplifies the preparation of financial statements for SMEs.

The directive excluded from the non-profit companies or businesses regulated by other sector-specific rules of their membership. As regards the general principles for the preparation of the financial statements, Arts. No. 4 and No. 6 reconfirm the same provisions contained in IV Directive, namely: the postulates of Level 1 (Art. 4) respectively of the "clarity" of the "accuracy" and "reality". To these are added the principles of the second level (Art. 6) that the new directive describes in more organic synthesis as described in the following in Table 2.

Table 2

The Postulates for Financial Statements

\begin{tabular}{|c|c|c|}
\hline General financial reporting principle & Directive No. 78/660/EEC & Directive 2013/34/EU \\
\hline Prudence & $\begin{array}{l}\text { It requires the recognition of the profit } \\
\text { only if they are made and all losses, even } \\
\text { if they are alleged, in order to guarantee } \\
\text { an income actually produced }\end{array}$ & $\begin{array}{l}\text { New directive emphasized the concept of } \\
\text { "product revenue" }\end{array}$ \\
\hline Going concern & $\begin{array}{l}\text { The assessment must be made according } \\
\text { to a going concern approach and not to } \\
\text { break up in order to attribute a value to } \\
\text { the assets of the company in relation to } \\
\text { their residual value }\end{array}$ & $\begin{array}{l}\text { New directive emphasizes that the } \\
\text { opening balance sheet of a financial year } \\
\text { must correspond perfectly to the closing } \\
\text { balance sheet of the previous year }\end{array}$ \\
\hline Competency & $\begin{array}{l}\text { Indicates that the costs and revenues } \\
\text { should be recognized only to the } \\
\text { portion of the actual economic } \\
\text { competence regardless of their actual } \\
\text { monetary event }\end{array}$ & Nothing changed \\
\hline $\begin{array}{l}\text { Separate evaluation of the heterogeneous } \\
\text { elements }\end{array}$ & $\begin{array}{l}\text { Heterogeneous items included in the } \\
\text { individual items must be valued } \\
\text { separately }\end{array}$ & Nothing changed \\
\hline Consistency evaluation criteria & $\begin{array}{l}\text { Highlights the use of the same evaluation } \\
\text { criteria in order to ensure the } \\
\text { comparability of the transactions }\end{array}$ & $\begin{array}{l}\text { Emphasizes the obligation to } \\
\text { communicate and justify the changes to } \\
\text { the evaluation criteria in order to avoid } \\
\text { misleading the accounting information }\end{array}$ \\
\hline Relevance & Not provided & $\begin{array}{l}\text { Introduced for the first time by Directive } \\
2013 / 34 \text { in order to emphasize the need to } \\
\text { detect and represent the values of the } \\
\text { financial statements in accordance with } \\
\text { the "substance" of transactions }\end{array}$ \\
\hline
\end{tabular}

It is also established that if the application of a provision of the directive was incompatible with the principles set out above, it must be set aside and therefore it must be indicated in the notes that fact and the reasons. 
Other provisions relating to the financial statements are contained in Art. No. 9 in which it is stated:

(1) The principle of non-changeability from one year to the next of the property to the balance sheet and income statement to comply with the comparability of the financial statements in future periods (formal “continuity principle”);

(2) The principle of the rigidity of the structure of the financial statements for the year. It is possible to modify the structure, nomenclature, and terminology of items only when the particular nature of the enterprise requires it; member states may permit or require the grouping of items preceded by Arabic numbers if a significant amount or such combination makes for greater clarity, but in the notes must be submitted separately. Member states may also insert further subdivisions to the voices of the financial statements preceded by roman numerals, to add to the total, partial, and additional items.

The 2013 EU accounting and transparency directives require disclosure in business registries in European Economic Area (EEA) countries and stock market repositories for companies engaged in extractive industries or logging of primary forests, too. Amounts below $€ 100,000$ in a financial year are exempt. Non-listed companies subject to the directive are those above two of the following three criteria: $€ 40$ million turnover, $€ 20$ million total assets, and 250 employees. Companies filing equivalent reports in a third country, e.g., to the US Securities and Exchange Commission (SEC), are also exempt. EU accounting directives currently require non-financial reporting on employment and environmental matters in company annual reports. A directive adopted by the European Parliament on April 15, 2014 will mandate that PIEs about 6,000, mainly listed, EU companies disclose in their annual reports policies, results, and risks on environmental, social, and employee-related matters, respect for human rights, anti-corruption, and bribery issues, and diversity on boards of directors (Verrecchia, 1998).

\section{The Measurement of the Financial Statement Items}

The directive states that the items of the financial statements should be evaluated primarily based on the purchase price or the cost of production (Art. 6, letter i). Special attention is devoted to fixed assets (Art. 7) and financial instruments (Art. 8) for which there are exceptions to the general principles.

As for the fixed assets, the legislature has held that member states may legislate in favor of the companies offering them the opportunity to proceed to the revaluation of fixed assets in order to make "faithful" to the reality the framework of the financial statements.

Therefore, unlike the previous legislation no longer provided for the "replacement value" and "appreciation value" as alternatives to the "purchase price" and the "cost of production", but it is held only the "revalued amount”.

With reference to financial instruments, including also "derivatives", the new directive provides that member states may authorize assessments to the "fair value" as described in Table 3.

Table 3

Principles for Valuation of Assets and Financial Instruments

\begin{tabular}{|l|l|l|}
\hline Measured component & Directive No. 78/660/EEC & Directive 2013/34/EU \\
\hline Assets & $\begin{array}{l}\text { Replacement value } \\
\text { Revaluation }\end{array}$ & Restating method (Article 7) \\
\hline Financial instruments & Market value & Fair value \\
\hline
\end{tabular}


With reference to the application of the "restating method", the directive provides that the amount of the difference between the valuation at purchase price or production cost and the assessment carried out by the method of recalculation be registered in the heading of "revaluation reserve within shareholders' equity". The revaluation reserve may not be reduced, except when the amounts charged to this reserve are no longer necessary for the application of the restatement method.

Member states may lay down rules governing the use of the revaluation reserve while respecting the provision that no part of the reserve may be distributed, directly or indirectly, unless it corresponds to a realized gain. The reserve may be wholly or partly converted into equity at any time.

The Italian legislation does not provide for a similar method at the time, but there are specific laws that allow the revaluation of certain types of assets (buildings and land) to take into account the real current value. The fair value method is an alternative method that can be applied to different types of assets. It is governed by Art. 9, according to which member states authorize or prescribe, for all companies or any classes of companies, the assessment of the fair value of financial instruments, including derivative financial instruments, and assets other than financial instruments. These factors include current assets and non-fixed assets, which are measured according to the restating method (Power, 2010).

The valuation based on the fair value applies only to the following liabilities:

(1) Liabilities held as part of the trading portfolio;

(2) Derivative financial instruments.

It does not apply to:

(1) Non-derivative financial instruments held to maturity;

(2) Loans and receivables originated by the enterprise and not held for trading purposes;

(3) Investments in subsidiaries, associates, and interests in joint ventures, equity instruments issued by the company, and contracts that provide for contingent consideration as part of a business combination, as well as other financial instruments whose special characteristics that, according to what is generally accepted, should be accounted for differently from other financial instruments.

The changes in value are included in the income statement, except in the cases listed below, in which these changes are recognized directly in a reserve of fair value of equity:

(1) The instrument accounted for is a hedging instrument, as part of a hedging transaction that allows to not enroll in the income statement for all or part of the change in value;

(2) The change in value relates to an exchange difference arising on a monetary item that forms part of an investment's net investment in a foreign entity.

Member states may permit or require that the change in value of a financial asset available for sale, other than a derivative financial instrument, be recognized directly in reserve of fair value. This is adjusted when amounts shown there are no longer necessary for the application of the method of the fair value (Pizzo, 2000).

Member states may permit or require all companies or for certain types of businesses that when an asset other than a financial instrument is valued at net book value, a change in value is recognized in the income statement.

The definition of fair value depends on the type of activity:

(1) Market value for financial instruments for which it is possible to easily locate a reliable market;

(2) Market value that can be derived from components or a similar instrument, if the market value is not readily identifiable for an instrument but can be identified for its components or for a similar instrument; 
(3) Market value resulting from models and valuation techniques generally accepted, provided that these models and valuation techniques ensure a reasonable approximation of the market value.

The advantages of the net method are to provide the latest data on the value of the assets, thus providing more accurate information, and the objectivity of the same, as determined by reference to the market value (Quagli, 2006).

The limitations are:

(1) The lack of accuracy when there are no markets considered that is based on values derived from models and measurement techniques for the estimation;

(2) The great variability of the value, linked to the difficulty in applying the method of the fair value than the purchase price or the cost;

(3) Greater difficulty in applying the method of the fair value than the purchase price or the cost.

This method is therefore the main effect of tying in part the trend of the performance to the market, which still constitutes a risk factor because of its potential volatility.

\section{The Structure of Financial Statement}

In order to ensure compliance with the postulates of the balance sheet and thus facilitate the internal and external stakeholders to understand and compare the analysis of balance sheets, profit, and financial enterprises (both domestic and European), the new EU directive reiterates the same way as the one currently in force that the structure of the balance sheet and income statement cannot be modified except in exceptional circumstances in line with these principles of "truthfulness", "fairness", and "clarity".

Article 4, Paragraph 1 indicates mandatory documents and certifies that the financial statements shall include at least the balance sheet, income statement, and the explanatory notes. In the previous version, the income statement was called "profit and loss" and the notes document was referred to as "attachments". In addition to these documents, member states may require additional prospectuses (Article 4, Paragraphs 1 and 2) as well as additional information (Article 4, Paragraphs 5 and 6) for medium-sized and large enterprises. Even in this circumstance is reiterated the need to simplify the administrative burden for small businesses. With regard to the format of the schemes, the directive prescribes the balance sheet (Annexes III and IV) and those of income statement (Annexes V and VI) and the contents of the notes in Chapter 4.

With reference to the balance sheet, there are two statements:

(1) A horizontal structure or opposing sections as required by the current Article 2424 of the Italian Civil Code. The scheme essentially corresponds to that in force providing some differences in classification and repositioning of the accounts of deleting accounts;

(2) A vertical structure or scalar of the accounts of assets and liabilities.

Article 10 provides for the possibility for member states to authorize a structure of the balance sheet based on the difference between current assets and current liabilities and those extra current.

Undoubtedly, the introduction into the Italian classification of items according to the "managerial relevance" and the possibility of a vertical structure represents a real innovation compared to what it can do today. It is clear that the discretion allowed to member states could undermine some of the objectives that the legislation is aimed first: the comparability of financial statements between companies located in the same state as well as between enterprises in different states. 
With regard to the income statement (Art. 13, Par. 1), the structures are set out in Annexes V and VI. In the first structure, the accounts are classified according to the scheme that follows the one in force and held Art. 2425 Civil Code, with showing some differences. In particular, the updated version has been simplified with the elimination of some items: macro items marked by letters have been eliminated leaving only the items marked by Arabic numerals. The new directive also provides for the elimination of grouping E) entitled "extraordinary income and expense".

This new rule is a modification not only formal but also substantial. The distinction between ordinary and extraordinary revenues and expenses must instead be compulsorily mentioned in the notes pursuant to Art. 16, Paragraph 1, letter f. Consequently, the income statement, which already makes it impossible to know in a rigorous way the operating profit in the year, loses further information value.

Annex VI regulates the structure of the income statement according to the functional approach ("as a function of spending”) according to which, the classification of items is based on the destination of the goods or services rather than by the nature of such goods.

The new directive does not provide for schemes in the income statement as opposed to sections but admits the possibility pursuant to Art. 13, C. 2 that member states may require or permit to replace the profit and loss statement with an account of the performance, provided the information.

With regard to the content of the notes, the new directive requires disclosures about the accounting policies adopted (Art. 16, Par. 1, letter a) to evaluate accounts of the financial statement and not the reference to the evaluation method.

Another innovation concerns the content of the note reformulated according to the size of company. The content, especially for small businesses, is significantly reduced compared to what is in force in accordance with Art. 2427 Civil Code. Instead, Art. 18 clarifies the additional content that is to be met only by large enterprises and by PIEs.

Among the other innovations, there is the possibility of drawing up the financial statements in an abbreviated form (Art. 31).

\section{Definitions Including PIEs}

Article 2 of the accounting directive (2013/34/EU, European Parliament, 2013) defines the following terms: PIEs, participating interest, related party, fixed assets, net turnover, purchase price, production cost, value adjustment, parent undertaking, subsidiary undertaking, group, affiliated undertaking, associated undertaking, investment undertakings, financial holding undertakings, and material.

PIEs mean undertakings which are:

(1) Governed by the law of a member state and whose transferable securities are admitted to trading on a regulated market of any member state within the meaning of Point (14) of Article 4 (1) of Directive 2004/39/EC of the European Parliament and of the Council of April 21, 2004 on markets in financial instruments;

(2) Credit institutions as defined in Point (1) of Article 4 of Directive 2006/48/EC of the European Parliament and of the Council of June 14, 2006 relating to the taking up and pursuit of the business of credit institutions, other than those referred to in Article 2 of that directive;

(3) Insurance undertakings within the meaning of Article 2 (1) of Council Directive 91/674/EEC of December 19, 1991 on the annual accounts of insurance undertakings; 
(4) Designated by member states as PIEs, for instance, undertakings that are of significant public relevance because of the nature of their business, their size, or the number of their employees.

For Italy, this relates principally to companies listed on the Main Market of the Italian Stock Exchange. The inclusion in the accounting directive, for the first time, of a definition of PIE is of interest. PIEs, broadly speaking, are defined as companies listed on a regulated exchange, credit institutions, and insurance undertakings. In addition, member states can designate as PIEs other undertakings that are of significant public relevance because of the nature of their business, their size, or the number of their employees, for example.

Significantly, companies defined as PIEs must report as large companies unless the accounting directive explicitly provides otherwise. This is because the extent to which PIEs are funded by the public and a high degree of transparency around their performance and financial position is considered necessary to allow fully informed decisions to be taken by members of the public before dealing with such an entity. As such, the simplified and reduced accounting requirements for small and medium-sized privately-owned companies are considered inappropriate for PIEs.

PIEs will always report in the same way as large undertakings regardless of their number of employees, total balance sheet, or turnover.

\section{Concluding Comments}

The new directive confirms the existing laws on the subject of financial statements through introducing a number of changes, most of which show more formal than substantial aspects. The main news regarding the financial statements is the introduction of alternative schemes of the income statement and balance sheet which are based on very different logic than the current ones. With regard to the aspect of the evaluation of balance sheet items, it is introduced alternative valuation of fixed assets, based on the "amounts restated" and also the alternative valuation based on the net amount which constitute only part of the news, because some of the predictions are already present in the existing legislation.

The legislation makes a rationalization of the financial statements adapting the features to the size of the quantitative parameters. However, the most important changes are optional in the sense that member states can choose when transposing whether or not to adopt them. In the Italian system, it will be unlikely to introduce radical innovations in the financial statements, because they are too alien to the current framework. The optional nature of many principles may be limits to the goal that puts the directive. In fact, the considerable discretion left to the member states may prevent the achievement of uniformity and consequently the comparison between the financial statements companies of different nationalities.

For these considerations and because the directive has not yet been transposed in Italy, it becomes difficult to express an opinion on the effects this could have on its effectiveness in achieving the objectives for which it was conceived.

Undoubtedly, there are many thoughts about the main innovations introduced by the directive, partly because the critical aspects contained in the new directive are many for whom the debate between professionals and associations is somewhat turned on. In the first place, the general approach of a modular basis so that the requirements on transparency of financial statements and governance should be proportional to the size and importance of the business even if viewed positively highlights some limitations. 
A simplification of administrative and accounting controls for small businesses in order to reduce the administrative burden is unlikely to highlight the critical issues typical of smaller companies, thus creating damage to the entire economic system. Even the approach to the provisions contained in the International Accounting Standards (IAS)/IFRS does not lend itself to SMEs. The information needs of SMEs are different, because they aim to meet the knowledge of other categories of stakeholders, such as banks, shareholders, business partners, and exchequers (Muller, Gagliardi, Caliandro, Bohn, \& Klitou, 2014).

For this reason, some accounting professionals believe that the evaluation principle based on the historical cost is still a valid measurement technique of the events, facts, and business operations. This does not mean that historical cost is the only method to be taken into consideration but the first to be used and where it is not suitable to represent properly the economic and financial situation of enterprises, it will be useful to identify alternative measurement techniques (Fortunato, 2007). In addition, the EU has revised the dimensional parameters in recent years several times in order to widen the scope of businesses that can provide accounting and regulatory simplification. A further increase of the thresholds considered also the continuing crisis period and the simultaneous decrease in the carrying value might not accurately represent the reality of SMEs. Excessive unpacking of the corporate reality envisaged by the directive is counterproductive, because:

(1) Providing multiple categories is likely to produce frequent changes in accounting models;

(2) It creates difficulties for operators forced to change the system setting data and significant complexity to the tax authorities who have to define an extra accounting mechanism to eliminate the differences arising from the simplifications.

For these reasons, it might be more appropriate to provide only two categories of reality, namely, small businesses and non-small businesses (in addition to PIEs).

It establishes a clear minimum reporting threshold, which should be these layouts stipulated in the directive and gives each member state the option of increasing the information required, without setting a maximum threshold. This may give rise to the discord between the countries in the Union and consequently, there may be different reporting thresholds depending on the country in question, once again departing from the harmonization in reporting by entities in the various countries. It prepares the ground for the coexistence of the two layouts for the balance sheet and the profit and loss account. The directive offers many options to member states for an arbitrary modification of the layouts as well as obligations in respect of publication and preparation of notes and management reports for micro and small companies, which may result in different financial reporting requirements and obligations in each member state.

\section{References}

Combarros, J. L. (2000). Accounting and financial audit harmonization in the European Union. European Accounting Review, 9(4), 643-654.

Corbella, S., Florio, C., \& Rossignoli, F. (2013). IFRS adoption in Italy: Which effects on accounting figures and subjectivity? Accounting and Finance Research, 2(4), 130-148.

European Commission. (2010). COM 543 final: Communication from the Commission to the European Parliament, the Council, the European Economic and Social Committee and the Committee of the Regions: Smart regulation in the European Union.

European Parliament. (2013). Directive 2013/34/EU. June 26, 2013.

Fortunato, S. (2007). Dal costo storico al "fair value”: Al di là della rivoluzione contabile. Rivista delle Società.

Muller, P., Gagliardi, D., Caliandro, C., Bohn, N. U., \& Klitou, D. (2014). Annual report on European SMEs 2013/2014 - A patrial and fragile recovery.

Pizzo, M. (2000). Il fair value nel bilancio d'esercizio. Padova: Cedam. 


\section{THE TRANSPOSITION OF DIRECTIVE 2013/34/EU INTO ITALIAN ACCOUNTING SYSTEM}

Power, M. (2010). Fair value accounting, financial economics, and the transformation of reliability. Accounting and Business Research, 40(3), 197-210.

Quagli, A. (2006). Bilancio di esercizio e principi contabili. Torino: Giappichelli.

Sottoriva, C. (2014). La riforma della redazione del bilancio di esercizio e del bilancio consolidato. Milano: Giuffré.

Verrecchia, R. E. (1998). Discussion of accrual accounting and equity valuation. Journal of Accounting Research, 36, 113-115. 